\title{
EFFECT OF POTASSIUM FERTILIZER, BIOSTIMULANTS AND EFFECTIVE MICROORGANISMS AS WELL AS THEIR INTERACTIONS ON POTATO GROWTH, PHOTOSYNTHETIC PIGMENTS AND STEM ANATOMY
}

Arafa, A.A.; S. Farouk and Hager S. Mohamed

Agric. Bot. Department, Faculty of Agric., Mansoura University

\begin{abstract}
Increasing potassium fertilizer rate up to $80 \mathrm{~kg} \mathrm{~K} \mathrm{~K}_{2} \mathrm{O} /$ fed significantly increased shoot fresh and dry weights, photosynthetic pigments concentration as well as stem anatomical characters. The highest weight was obtained due to application of $40 \mathrm{~kg}$ $\mathrm{K}_{2} \mathrm{O} /$ fed in the first and seconds season as compared with untreated plants. Exogenous application of biostimulants, in particular, seaweed extract significantly increased shoot fresh and dry weights, photosynthetic pigment concentration as well as increased the diameter of stem, pith and thickness of collenchyma layers, and xylem tissue as well as the length and width of large vascular bundle beside the thickness of external phloem as compared to control in both seasons. Addition of effective microorganisms to the soil significantly increased shoot fresh and dry weight, photosynthetic pigments concentration as well as the diameter of stem, length and width of vascular bundle, and the thickness of xylem.

As for the interactions, application of bostimulants, in particular, seaweed extract, significantly increased fresh and dry weights of potato shoot, photosynthetic pigments concentration as well as improved anatomical characteristics of potato stem grown under all potassium fertilizer rates with or without anaddition of effective microorganisms. The highest value was obtained under the treatment of $40 \mathrm{~kg}$ $\mathrm{K}_{2} \mathrm{O} /$ fed with addition of effective microorganisms and spraying plants with $500 \mathrm{mg} / \mathrm{l}$ seaweed extract as compared with control plant in the first and second growing seasons.
\end{abstract}

\section{INTRODUCTION}

Potato (Solanum tuberosum L.) rates fourth among the world's various agricultural products in production volume, after wheat, rice and corn (Fabeiro et al., 2001). It contains high levels of carbohydrates and significant amounts of vitamins B and C and other minerals (Pondey and Chadha, 1996). Potato demands high level of soil nutrients due to relatively poorly developed and shallow root system in relation to yield (Perrenoud, 1993). This high rate of dry matter production results in large amounts of nutrients removed per unit time, which generally most of the soils are not able to supply. Hence, nutrient application from external sources as fertilizers becomes essential. According to Perrenoud (1993), a crop yielding 37 ton ha $^{-1}$ removes $113 \mathrm{~kg} \mathrm{~N}, 45 \mathrm{~kg}$ $\mathrm{P}_{2} \mathrm{O}_{5}$ and $196 \mathrm{~kg} \mathrm{~K}_{2} \mathrm{O}$ ha-1. Potato crop is a heavy remover of soil potassium and is the nutrient taken up in the greatest quantity; the tuber removes 1.5 times as much potassium as nitrogen and $4-5$ times the amount of phosphate (Perrenoud, 1993). The importance of potassium (K) fertilization in the egyptian agriculture has risen since the completion of the High Dam that resulted in the deposition of the suspended Nile silt in the upstream of the 
Arafa, A.A. et al.

formed lake. This Nile silt enriched the egyptian soils with $K$ during the seasonal floods (Abd El-Hadi et al., 1997). However, continuous cropping without replenishing nutrients can cause an irreparable damage to soil fertility. A $\mathrm{K}$ deficiency may affect respiration, photosynthesis, chlorophyll development, and water content of leaves (Sangakkara et al., 2000). Potassium increases the photosynthetic rates of crop leaves and carbon dioxide $\left(\mathrm{CO}_{2}\right)$ assimilation, and facilitates carbon movement (Sangakkara et al., 2000). Potassium nutrition has pronounced effects on carbohydrate partitioning by affecting either phloem export of photosynthates (sucrose) or growth rate of sink and/or source organs (Cakmak et al., 1994). Furthermore, $\mathrm{K}$ plays an important role in the translocation of photosynthates from source to sink (Cakmak et al., 1994).

Using biofertilizers in potato production in Egypt to produce safety yield and free of harmful chemicals and toxic materials is well recommended to take place in european market, and to have the consumer who is willing to pay high rate price for healthy safe product. Effective microorganisms' stock solution "EM" is one of many biofertilizers used in this concern. EM as a biofertilizer was first used in Japan by Higa (1995), it contains a group of beneficial microorganisms (primary photosynthetic and lactic acid bacteria, yeast, acinomycetes and fermenting fungi) which are cultured and used for many proposes; a) promotes germination, flowering, fruiting and ripening in plants, b) improves physical, chemical and biological environments of the soil and suppresses soil borne pathogens and pests, c) enhances he photosynthetic capacity of crops. EM can be used by two ways; watering into the soil and foliar spray.

Natural products, which contain phytohormones or exhibit hormone-like activity, have received increasing attention for use as nutrients supplements in agriculture and horticulture (Seadh et al, 2008, Ezzat et al., 2011). Seaweed extracts (SW) (Ascophyllum nodosum Jol.) and humic acid (HA) are in common use as major components of vegetable and crop biostimulatant formulations. Auxine and cytokinin-like activities of humic acids have been reported (Piccolo et al., 1992). Cytokinins and auxine have been identified and quantified in SW (Sanderson et al., 1987). These natural products have been shown to enhance plant growth under normal or stressed condition (Seadh et al., 2008; Ezzat et al., 2011). Humic acid is considered to increase the permeability of plant membranes and enhance the uptake of nutrients. Moreover, humic acid is also considered to improve soil nitrogen uptake and encourage the uptake of potassium, calcium, magnesium and phosphorus, making these more mobile and available to plant root system (Piccolo et al., 1997; Pascual et al., 1999).

The aim of the present study was to clarify the effect of various biostimulators (Seaweed extract and Humic acid) and effective microorganisms as well as potassium rates on potato growth, photosynthetic pigment concentration and stem anatomy. It is the main hope to find out the most favorable treatments producing more growth and pigment concentration in potato plant. It was further hoped that the results of this work finally may lead to the utilization of one or more of these chemicals for large scale cultivation of potato under field condition. 


\section{MATERIALS AND METHODS}

Two field experiments were conducted during the two successive winter seasons of 2007/2008 and 2008/2009 at the EL-Maniel village, Dakhlia Governorate to study the effect of effective microorganisms, biostimulants, and potassium levels as well as their combinations on the potato plant growth, photosynthetic pigment concentration and stem anatomy.

\section{Soil samples and analysis:}

Twenty surface samples $(0-20 \mathrm{~cm}$ depth) were taken at ten different locations. The experimental soil was air dried, grounded, mixed and kept in plastic bags for the analyses. The mechanical and chemical analyses of the soil used were carried out in the two growing seasons and presented in Table (I).

Table (1): Mechanical and chemical soil characteristics at the experimental sites during 2007/2008 and 2008/2009

\begin{tabular}{|c|c|c|c|c|c|c|c|c|}
\hline \multirow[b]{2}{*}{$\begin{array}{l}\text { Physical } \\
\text { properties }\end{array}$} & \multicolumn{2}{|c|}{ Value } & \multirow[b]{2}{*}{$\begin{array}{l}\text { Chemical } \\
\text { properties }\end{array}$} & \multicolumn{2}{|c|}{ Value } & \multirow{2}{*}{$\begin{array}{c}\text { Available } \\
\text { nutrients (mg } \\
\left.\mathrm{Kg}^{-1}\right)\end{array}$} & \multicolumn{2}{|c|}{ Value } \\
\hline & $\begin{array}{c}1^{\text {st }} \\
\text { season }\end{array}$ & $\begin{array}{c}2^{\text {nd }} \\
\text { season }\end{array}$ & & \begin{tabular}{|c|}
$1^{\text {st }}$ \\
season
\end{tabular} & $\begin{array}{c}2^{\text {nd }} \\
\text { season }\end{array}$ & & $\begin{array}{c}1^{\text {st }} \\
\text { season }\end{array}$ & $\begin{array}{c}2^{\text {nd }} \\
\text { season }\end{array}$ \\
\hline Sand \% & 21.0 & 21.1 & Field capacity $\%$ & 32 & rr & Nitrogen & 19 & 18 \\
\hline Silt\% & 32.3 & 33.0 & $\mathrm{EC}(\mathrm{dSm}-1)$ & 1.64 & 1.70 & phosphorous & 8 & 7 \\
\hline Clay \% & 46.0 & 45.8 & $\mathrm{pH}$ (Soil paste) & 7.82 & 7.75 & Potassium & 140 & 135 \\
\hline Soil te & clay & & $\begin{array}{c}\text { Organic matter } \\
(\%)\end{array}$ & 2.69 & 2.80 & & & \\
\hline
\end{tabular}

Plant Material, EM, Humic acid, and Seaweed Extract

Potatoes tubers; cv Spunta (imported from Holland) were used in the present investigation and obtained from Agric. Res. Center (ARC), Ministry of Agric., Egypt. Tubers were divided to pieces, averaging approximately $50 \mathrm{~g}$ weight. As recommended by the Pathology Dept. Ministry of Agric. Egypt, potato tubers pieces were sterilized with Vitavax Kapetan 1\% at the rate of $1.25 \mathrm{~kg} / \mathrm{ton}$.

Effective micro-organisms were used under the name of EM which consists of a mixed culture of beneficial micro-organisms primarily photosynthetic and lactic acid bacteria, yeast and streptomycetes. The number of each component was recorded in table (2)

Table (2): Components of EM used in the experiments

\begin{tabular}{|c|c|c|c|}
\hline Total bacterial & Lactic acid bacteria & yeasts & Streptomycetes \\
\hline $2.5-9.6 \times 10^{4} \mathrm{cfu} / \mathrm{ml}$ & $6.6-9.9 \times 10^{6} \mathrm{cfu} / \mathrm{ml}$ & $10^{5}-10^{6} \mathrm{cfu} / \mathrm{ml}$ & $8.5 \times 10^{3} \mathrm{cfu} / \mathrm{ml}$ \\
\hline
\end{tabular}

An extract from brown seaweed (Acadian Seaplants, Dartmouth, Nova Scotia, Canada) prepared by a proprietary process. Seaweed extract is derived by an alkaline hydrolysis procedure from the fresh, intact Ascophyllum nodosum and $100 \%$ soluble in cold water. Seaweeds contained all the trace elements and plant growth hormones vitamins, amino acids, antibiotic and micronutrients (Crouch and Van Staden, 1993). Also seaweed extract contained protein/amino acids $3-5 \%$, lipid $1 \%$, alginic acid $12-18 \%$, fucose-containing polymers $12-15 \%$, mannitol $5-6 \%$, other carbohydrates 
Arafa, A.A. et al.

10-15\% (Acadian Seaplants Limited, Dartmoth, Nova Scotia, Canada), As described by Fike et al., (2001).

Experimental design:

Farm yard manure has been added during soil preparation in organic fertilization at dose $\left(40 \mathrm{~m}^{3} / \mathrm{fed}\right.$.). The experiment comprised of 18 treatments including three different rates of potassium fertilizers used individually or in combinations with EM and biostimulants (Humic acid or seaweed extract). A randomized complete block design in factorial arrangement was used with three replicates. Each plot was $7.2 \mathrm{~m}^{2}\left(2.25 \times 3.20 \mathrm{~m}^{2}\right)$ included three ridges, each three meters long and $70 \mathrm{~cm}$ apart; the distance between hills was 30 $\mathrm{cm}$ apart.

\section{Planting procedure:}

Potato tuber cv. Spunta was planted in the ridges at $12-15 \mathrm{~cm}$ in depth (30-40 $\mathrm{cm}$ apart) on October $27^{\text {th }}$ in the first season $2007 / 2008$ and on November $9^{\text {th }}$ in the second season 2008/2009 respectively. Potassium (K) levels occupied the main plots, while the effective microorganisms (EM) were assigned to the sub-plots, in each EM sub-plot the plants were divided into three groups which sprayed with either water (W), seaweed extract (SW) or humic acid (HA). The plot area was $7.2 \mathrm{~m}^{2}$ ridged $70 \mathrm{~cm}$ apart.

As recommended by the Agric. Res. Center, Egypt, Nitrogen fertilizer was added at three equal portions, the $1^{\text {st }}$ was applied after emergence (1821 days from planting), in the form of ammonium sulphate (20.5\%), then two and four weeks later in the form of ammonium nitrate $(33.5 \%)$ at the rate of $180 \mathrm{Kg} \mathrm{N} /$ fed. Phosphorous and potassium were applied during the soil preparation in the form of calcium superphosphate $\left(15.5 \% \quad \mathrm{P}_{2} \mathrm{O}_{5}\right)$ and potassium sulphate $\left(48 \% \mathrm{~K}_{2} \mathrm{O}\right)$ at rate of $75 \mathrm{~kg} \mathrm{P}_{2} \mathrm{O}_{5} / \mathrm{fed}$ and $20 \mathrm{~kg} \mathrm{~K}_{2} \mathrm{O}$ fed -1 respectively. The respective EM treated plots received dilute EM solution 2 liter $/ \mathrm{m}^{2}$ before the first irrigation. Potassium fertilizers applied at three levels 0,40 and $80 \mathrm{~kg} \mathrm{~K}_{2} \mathrm{O} \mathrm{fed} \mathrm{f}^{-1}$ using potassium sulphate $\left(48 \% \mathrm{~K}_{2} \mathrm{O}\right)$. The quantity was divided into two equal doses to be added before the first irrigation and before the second irrigation. Plants were sprayed with an aqueous solution of SW or HA two times at 60 and 75 days from planting. Irrigation was done immediately. All usual cultural practices of potatoes cultivation were carried out according to the procedures that recommended by the Ministry of Agric. Egypt. Harvesting was done after 115 days from planting dates in both seasons.

\section{Sampling dates and data recorded:}

One plant sample was taken throughout the experimental period during the two growing seasons, for the growth characters and photosynthetic pigment determination and stem anatomy coincide as best as possible at the physiological stage of 22 foliageleaves; dated at the active growth period (after 90 days from planting). Growth characters: three plants were chosen randomly and carefully taken out of the soil with the aid of a water stream to insure minimal losses of the root system and the tubers if present. Fresh and dry weight of shoot $(\mathrm{g})$ was recorded. Photosynthetic pigments concentration in the $4^{\text {th }}$ upper leaf $(\mathrm{mg} / \mathrm{g} \mathrm{FW})$ was extracted in methanol over night. The quantity of photosynthetic pigments in leaves was determined by the equation introduced by Lichtenthaler and Wellburn (1985). For anatomical studies, 
small pieces $(5 \mathrm{~mm})$ from the middle part of the $3^{\text {rd }}$ internode from the plant tip were taken after 90 days from planting. The samples were killed and fixed in formalin aceto alcohol for at least $48 \mathrm{~h}$, then washed and dehydrated in series of ethanol and embedded in paraffin wax (52-54 ${ }^{\circ} \mathrm{C}$ melting point). Cross sections were done at $12-15 \mu \mathrm{m}$ thick using rotary microtome, stained in Saffranin/light green combination, cleared in cloves oil and mounted in canada balsam.

Statistical analysis:

Data were subjected to statistical analysis of variance according to Norman and Streiner, 2003. LSD value was used to test the difference between treatment means at $5 \%$.

\section{RESULTS AND DISCUSSION}

\section{Shoot fresh and dry weight:}

The effects of potassium fertilizers rates, biostimulants application or effective microorganisms addition and their interactions on shoot fresh and dry weights $(\mathrm{g} / \mathrm{plant})$ are illustrated in figures $(1,2)$ and presented in tables $(3,4)$. Data illustrated in figures $(1,2)$ indicated that increasing potassium fertilizer rate up to $80 \mathrm{~kg} \mathrm{~K} \mathrm{~K}_{2} \mathrm{O} /$ fed significantly increased shoot fresh and weights. The highest weight was obtained due to application of $40 \mathrm{~kg} \mathrm{~K} 2 \mathrm{O} / \mathrm{fed}$ in the first and second season as compared with untreated plants. As regard to the effect of biostimulants, the data illustrated in the same figures cleary showed that application of either seaweed extract or humic acid as foliar application significantly increased shoot fresh weight as compared to control in both seasons. Seaweed extract was more effective than humic acid in increasing shoot fresh and dry weight as compared to foliar application of water. Also, the same figure reveald that addition of effective microorganisms to the soil significantly increased shoot fresh weight.
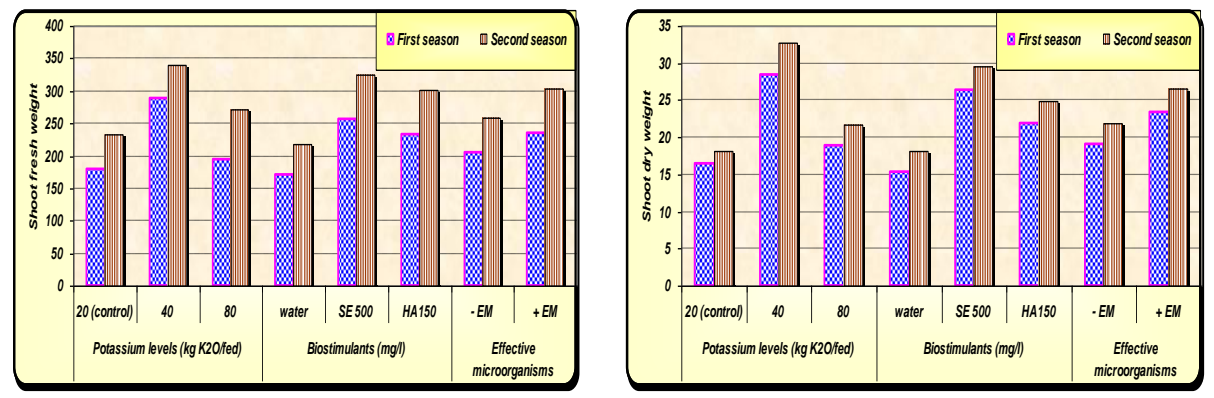

Figure $(1,2)$ Shoot fresh and dry weights $(g)$ of potato plant as affected by potassium fertilizer, biostimulants or effective microorganisms at 90 days from planting in both seasons (SE, Seaweed extract; HA, Humic acid)

As for the interactions, data in the tables $(3,4)$ showed that application of either biostimulants, in particular, seaweed extract, significantly increased fresh and dry weight of potato shoot grown under all potassium fertilizer rates 
Arafa, A.A. et al.

with or without addition of effective microorganisms. The highest value was obtained under an addition of $40 \mathrm{~kg} \mathrm{~K} \mathrm{~K} / \mathrm{fed}$ with addition of effective microorganisms and spraying plants with $500 \mathrm{mg} / \mathrm{l}$ seaweed extract as compared with control plant in the first and second growing seasons.

Table (3): Shoot fresh weight $(\mathrm{g})$ of potato plant as affected by the interactions between potassium fertilizer (A), effective microorganisms (B) and biostimulants (C) at 90 days from planting during the first and second season

\begin{tabular}{|c|c|c|c|c|c|c|}
\hline \multirow{3}{*}{ Treatment } & \multicolumn{6}{|c|}{ First season } \\
\hline & \multicolumn{3}{|c|}{ - EM } & \multicolumn{3}{|c|}{$+\mathrm{EM}$} \\
\hline & $\mathrm{K}_{20}$ & $\mathrm{~K}_{40}$ & $K_{80}$ & $\mathrm{~K}_{20}$ & $\mathrm{~K}_{40}$ & $K_{80}$ \\
\hline Water & 139.96 & 190.06 & 152.10 & 150.03 & 217.50 & 174.96 \\
\hline SE & 191.20 & 320.16 & 194.20 & 210.23 & 390.63 & 232.33 \\
\hline $\mathrm{HA}$ & 180.73 & 293.46 & 185.63 & 203.10 & 307.93 & 227.33 \\
\hline LSD 5\% & \multicolumn{2}{|c|}{ A 7.322} & .865 & \multirow[t]{2}{*}{ C 6.588} & \multicolumn{2}{|c|}{$\mathrm{ABC} 16.137$} \\
\hline \multicolumn{6}{|c|}{ Second season } & \\
\hline Water & 136.16 & 248.80 & 215.70 & 186.00 & 302.16 & 221.53 \\
\hline SE & 255.60 & 377.40 & 278.93 & 297.60 & 404.96 & 340.43 \\
\hline $\mathrm{HA}$ & 232.20 & 345.00 & 247.43 & 292.13 & 361.56 & 326.76 \\
\hline LSD $5 \%$ & \multicolumn{2}{|c|}{ A 22.71} & .519 & C 8.165 & \multicolumn{2}{|c|}{ ABC 20.000} \\
\hline
\end{tabular}

(K20, 20 kg K2O/ fad; K40, 40 kg K2O/ fad; K80, 80 kg K2O/ fad; SE, seaweed extract; HA, humic acid)

Table (4): Shoot dry weight (g/plant) of potato plant as affected by the interactions between potassium fertilizer (A), effective microorganisms (B) and biostimulants (C) at 90 days from planting during the first and second season

\begin{tabular}{|c|c|c|c|c|c|c|}
\hline \multirow{2}{*}{ Treatment } & \multicolumn{7}{|c|}{ First season } \\
\cline { 2 - 7 } & \multicolumn{7}{|c|}{$\mathbf{K}_{\mathbf{2 0}}$} & $\mathbf{K}_{\mathbf{4 0}}$ & $\mathbf{K}_{\mathbf{8 0}}$ & $\mathbf{K}_{\mathbf{2 0}}$ & $\mathbf{K}_{\mathbf{4 0}}$ & $\mathbf{K}_{\mathbf{8 0}}$ \\
\cline { 2 - 7 } & 12.73 & 16.96 & 14.10 & 13.53 & 19.83 & 15.46 \\
\hline Water & 17.40 & 35.40 & 18.03 & 19.66 & 43.16 & 24.90 \\
\hline SE & 15.80 & 23.86 & 16.76 & 19.23 & 31.80 & 23.73 \\
\hline HA & A 1.265 & \multicolumn{7}{|c|}{ B 0.319 } & C 0.685 & ABC \\
\hline LSD 5\% & \multicolumn{7}{|c|}{ Second season } \\
\hline Water & 13.50 & 18.66 & 16.56 & 14.80 & 27.46 & 17.66 \\
\hline SE & 19.66 & 41.20 & 20.30 & 22.30 & 45.20 & 29.26 \\
\hline HA & 18.16 & 30.66 & 18.36 & 20.63 & 33.36 & 28.00 \\
\hline LSD 5\% & A 3.928 & B 0.702 & C 1.149 & ABC 2.815 \\
\hline
\end{tabular}

(K20, 20 kg K2O/ fad; K40, 40 kg K2O/ fad; K80, 80 kg K2O/ fad; SE, seaweed extract; HA, humic acid)

Potassium application, in particular, $40 \mathrm{~kg} \mathrm{~K}_{2} \mathrm{O} / \mathrm{fed}$ improved plant growth represented as shoot fresh and dry weights under the condition of the present investigation. This results are confirmed with many investigations (Moinuddin et al., 2005 and Ahmed et al., 2009); and recently by Bhattacharyya et al. (2009) who indicated that application of $180 \mathrm{~kg} \mathrm{~K} 2 \mathrm{O} / \mathrm{ha}$ recorded higher values of growth attributes. It is well known that, potassium is the most important inorganic osmotic component and stimulates growth primarily by its effects on cell extension (Mengel and Arneke, 1982). Moreover, application of $\mathrm{K}$ increased the availability of nitrogen and 
phosphorus (Sahai, 2004) which resulted in better plant growth and more number of branches per plant.

It is well known from the present investigation that application of humic acid significantly increased plant growth characteristics. The obtained results were confirmed with Seadh et al. (2008) on wheat, El-Ghamry et al., (2009) on faba bean, Verlinden et al. (2009) on grass, maize, potato and spinach, and Saif El-Deen et al. (2011) on sweet potato plants. The mechanism by which humic acid stimulates plant growth are not fully clear, although there are some theories which probably work together. In general, humic acid have two important roles for the development of plants, either directly or indirectly (Nardi et al., 1996) but the mechanism still remain unclear. So far hormonelike substances have been elucidated to understand the mechanism of humic substances in plant metabolism (Muscolo et al., 1999) through their involvement in cell respiration, photosynthesis, oxidative phosphorylation, protein synthesis, and various enzymatic reactions (Zhang et al., 2003). It is possible that the enhancement in the growth of potato plants, after application of humic acid, could be attributed at least partially to increased nutrient uptake by the plants. In this concern, HA has been reported to enhance mineral nutrient uptake by plants, by increasing the permeability of membranes of the root cells (Valdrighi et al., 1996).

The obtained results in the present investigation showed an increase in potato plant growth after seaweed extract foliar application. Similar results have been reported on okra (Zodape et al., 2008) and on tomato (Zodape et al., 2011). In this concern, Zodape et al., (2011) found that foliar application of seaweed extract on tomato shoot increased plant growth represented as plant height, root length over control plants. Besides, their application as farmyard manure, liquid extracts obtained from seaweeds have gained importance as foliar sprays for several crops, because the extract contains growth promoting hormones (IAA and IBA), cytokinins, trace elements ( $\mathrm{Fe}, \mathrm{Cu}, \mathrm{Zn}, \mathrm{Co}, \mathrm{Mo}, \mathrm{Mn}, \mathrm{Ni}$ ), vitamins and amino acids (Sridhar and Rengasamy, 2002). The positive effect of SE on plant growth may be due to its effect on increasing phosphorous uptake and content as recorded in the present investigation. Phosphorous is an essential nutrient and it plays an important role in the biosynthesis and translocation of carbohydrates and is necessary in stimulating cell division and the formation of DNA and RNA (Nijjar, 1985).

The present investigation indicated that an addition of EM increased, in most cases, growth parameters of potato plants. The results in this connection are in agreement with those found by many authors, i.e. AbouBakr et al. (2005) on potato plant, who indicated that application of EM at (1, 5 , and $10 \mathrm{ml} / \mathrm{l}$ ) induced significant increases in plant height, number of stems per plant, number of leaves per plant, total leaf area per plant in both seasons. The improvement in growth characters may be attributed to the fact that the use of EM enhances the beneficial microbes in the environment, which attributed to the profound effect of a) its ability to release plant growth promoting substances which might be stimulated plant growth, b) synthesis of some beneficial organic acids, bioactive substances and vitamins, c) increasing amino acids content (Schank et al., 1981), d) increasing in the 
Arafa, A.A. et al.

water and mineral uptake from the soil leading to improving the availability and acquisition of nutrients from the soil (Sarig et al., 1984) due to increases in root surface area, root hairs and root elongation (Sundaravelu and Muthukrishinan, 1993), e) increasing the ability to convert nitrogen to ammonium and thus make it available to plant, f) enhancing the production of biologically active fungistatical substances which may change the microflora in the rhizosphere and affect the balance between harmful and beneficial organisms (Apte and Shende, 1981), and g) improving the photosynthetic efficiency due to an increase in nutrient availability. Many actual and putative plant growth producing bacteria containing in EM produce phytohormones that are believed to be related to their ability to stimulate plant growth. In most cases, these phytohormones are believed to be changing assimilate partitioning patterns in plants and affecting growth patterns in roots to result in bigger roots, more branched roots, and/or roots with greater surface area. Indole-3-acetic acid is a phytohormone which is known to be involved in root initiation, cell division, and cell enlargement (Salisbury, 1994).

\section{Photosynthetic pigments:}

Data presented in Tables $(5,6)$ and Figures $(3,4,5)$ showed that the content of photosynthetic pigments in the leaves of potato plants subjected to potassium fertilizers was higher than control plants. In this concern, an addition of $40 \mathrm{~kg} \mathrm{~K} \mathrm{~K}_{2} \mathrm{O}$ fed gave the highest values of photosynthetic pigments. On the other hand, application of potassium fertilizer did notsignificantly decreased the ratio between chlorophyll $A$ and chlorophyll $B$, and the moderate potassium level gave the lowest ratio in this respect.

The data presented in Tables $(5,6)$ revealed that all interactions between potassium fertilizer rates, addition of effective microorganisms and spraying biostimulants (seaweed extract or humic acid) significantly increased the content of chlorophyll $B$ and total chlorophylls in the $3^{\text {rd }}$ upper compound leaf of potato plant at 90 days from planting during the second growing season, but non-significantly increased either chlorophyll A or carotenoid contents in the same leaf as compared with control plants. On the other hand, the ratio between chlorophyll A and chlorophyll B was nonsignifcantly decreased in the leaves comparing with the untreated plants. The highest values of photosynthetic pigment contents (Chlorophyll A "1.112", chlorophyll B "0.509", total chlorophylls "1.622", and total carotenoids "0.563" mg/g FW) were obtained due to spraying potato shoot with seaweed extract, and an addition of $40 \mathrm{~kg} \mathrm{~K} \mathrm{~K}_{2} \mathrm{O} / \mathrm{fed}$ with addition of effective microorganisms as compared with control plants $(0.722,0.129,0.851$ and $0.103 \mathrm{mg} / \mathrm{g}$ FW respectively).

The data presented in Table (5) indicated that an addition of EM to potato plants significantly increased chlorophyll $B$, total chlorophylls, and total carotenoids contents in the leaves whereas; the increase in chlorophyll A content was insignificant. Meanwhile, an addition of EM significantly decreased the ratio between chlorophyll $A$ and chlorophyll $B$. Regarding the effect of biostimulants on photosynthetic pigments content, the data illustrated in Figures $(3,4,5)$ clearly showed that application of either seaweed extract or humic acid significantly increased photosynthetic pigments, 
whereas significantly decreased chlorophyll A/ chlorophyll B ratio. However, seaweed extract was more effective than humic acid on increasing photosynthetic pigments content and decreasing the ratio between chlorophyll A and chlorophyll B.

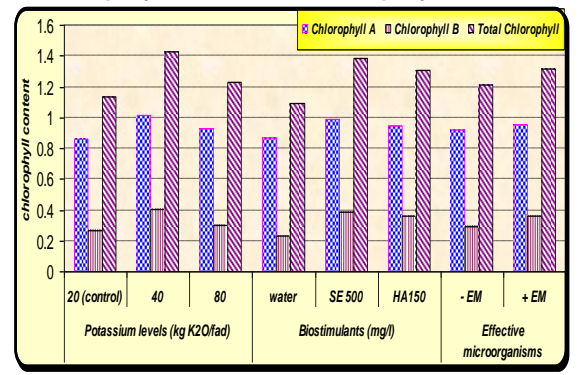

Figure (3): Chlorophyll A, chlorophyll B and total chlorophyll content in the $3^{\text {rd }}$ upper compound leaf of potato plant (mg/g FW) as affected by potassium fertilizer, biostimulants or effective microorganisms at 90 days from planting during the second growing season

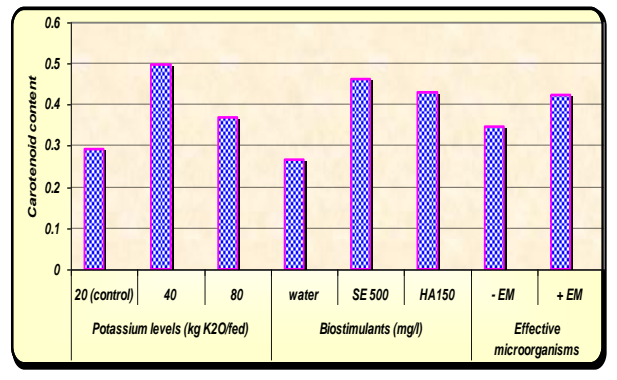

Figure (4): Total carotenoid content in the $3^{\text {rd }}$ upper compound leaf of potato plant $(\mathrm{mg} / \mathrm{g} \mathrm{FW})$ as affected by potassium fertilizer, biostimulants or effective microorganisms at 90 days from planting during the second growing season (SE, Seaweed extract; HA, Humic acid)

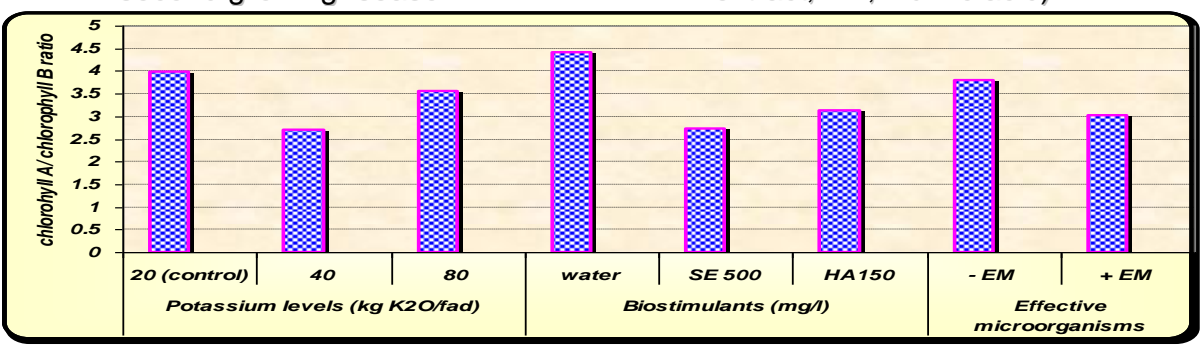

Figure (5):The ratio between chlorophyll $A$ and chlorophyll $B$ in the $3^{\text {rd }}$ upper compound leaf of potato plant $(\mathrm{mg} / \mathrm{g} \mathrm{FW})$ as affected by potassium fertilizer, biostimulants or effective microorganisms at 90 days from planting during the second growing season(SE, Seaweed extract; HA, Humic acid)

The effect of potassium on photosynthetic pigments was also reported by Shehata and Abo-Sedera (1994). In this concern, El-Sawy (2011) on sweet potato found that increasing potassium levels from 25 upto $75 \mathrm{~kg} / \mathrm{fed}$ significantly increased total chlorophyll content compared with untreated plants. Moreover, Rai et al. (2004) observed that the chlorophyll content in leaves $(0.235$ to $0.425 \mathrm{mg} / 100 \mathrm{~g})$ increased significantly with increasing levels of potassium.

Increasing of photosynthetic pigments due to application of HA may be due to increasing the uptake of magnesium and iron, which are required for chlorophyll biosynthesis. This result was reported previously, where, application of potassium humate significantly increased chlorophyll content in 
Arafa, A.A. et al.

leaves (Seadh et al. 2008, El-Ghamry et al. 2009 and Saif El-Deen et al. 2011).

Table (5): Chlorophylls content in the $3^{\text {rd }}$ upper compound leaf of potato plant $(\mathrm{mg} / \mathrm{g} \mathrm{FW}$ ) as affected by the interactions between potassium fertilizer (A), effective microorganisms (B) and biostimulants (C) at 90 days from planting during the second growing season

\begin{tabular}{|c|c|c|c|c|c|c|}
\hline \multirow{3}{*}{ Treatment } & \multicolumn{6}{|c|}{ Chlorophyll A } \\
\hline & \multicolumn{3}{|c|}{ - EM } & \multicolumn{3}{|c|}{+ EM } \\
\hline & $\mathrm{K}_{20}$ & $\mathrm{~K}_{40}$ & $\mathrm{~K}_{80}$ & $\mathrm{~K}_{20}$ & $\mathrm{~K}_{40}$ & $\mathrm{~K}_{80}$ \\
\hline Water & 0.722 & 0.945 & 0.865 & 0.839 & 0.948 & 0.894 \\
\hline SE & 0.850 & 1.108 & 0.936 & 0.926 & 1.112 & 1.028 \\
\hline $\mathrm{HA}$ & 0.960 & 0.941 & 0.940 & 0.866 & 1.058 & 0.920 \\
\hline LSD 5\% & \multicolumn{2}{|l|}{ A 0.018} & NS & \multicolumn{2}{|c|}{ C 0.019} & ABC NS \\
\hline \multicolumn{7}{|c|}{ Chlorophyll B } \\
\hline Water & 0.129 & 0.264 & 0.213 & 0.145 & 0.369 & 0.270 \\
\hline SE & 0.343 & 0.416 & 0.332 & 0.375 & 0.509 & 0.361 \\
\hline $\mathrm{HA}$ & 0.196 & 0.484 & 0.235 & 0.422 & 0.389 & 0.417 \\
\hline LSD 5\% & \multicolumn{2}{|c|}{ A 0.019} & .014 & \multicolumn{2}{|c|}{ C 0.020} & ABC 0.049 \\
\hline \multirow{3}{*}{ Treatment } & \multicolumn{6}{|c|}{ Total Chlorophylls } \\
\hline & \multicolumn{3}{|c|}{ - EM } & \multicolumn{3}{|c|}{$+\mathrm{EM}$} \\
\hline & $\mathrm{K}_{20}$ & $\mathrm{~K}_{40}$ & $\mathrm{~K}_{80}$ & $\mathrm{~K}_{20}$ & $\mathrm{~K}_{40}$ & $\mathrm{~K}_{80}$ \\
\hline Water & 0.851 & 1.209 & 1.079 & 0.984 & 1.318 & 1.131 \\
\hline SE & 1.227 & 1.524 & 1.269 & 1.303 & 1.622 & 1.386 \\
\hline $\mathrm{HA}$ & 1.157 & 1.426 & 1.174 & 1.289 & 1.448 & 1.337 \\
\hline LSD 5\% & A 0.002 & \multicolumn{2}{|c|}{ B 0.004} & C 0.00 & \multicolumn{2}{|c|}{ ABC 0.015} \\
\hline
\end{tabular}

(K20, 20 kg K2O/ fad; K40, 40 kg K2O/ fad; K80, 80 kg K2O/ fad; SE, seaweed extract; HA, humic acid)

Table (6): Total carotenoid content( $\mathrm{mg} / \mathrm{g} \mathrm{FW}$ ) and the ratio between chlorophyll $A$ and chlorophyll $B$ in the $3^{\text {rd }}$ upper compound leaf of potato plant as affected by the interactions between potassium fertilizer (A), effective microorganisms (B) and biostimulants (C) at 90 days from planting during the second growing season

\begin{tabular}{|c|c|c|c|c|c|c|}
\hline \multirow{3}{*}{ Treatment } & \multicolumn{6}{|c|}{ Total carotenoids } \\
\hline & \multicolumn{3}{|c|}{ - EM } & \multicolumn{3}{|c|}{$+\mathrm{EM}$} \\
\hline & $\mathrm{K}_{20}$ & $\mathrm{~K}_{40}$ & $\mathrm{~K}_{80}$ & $\mathrm{~K}_{20}$ & $\mathrm{~K}_{40}$ & $\mathrm{~K}_{80}$ \\
\hline Water & 0.103 & 0.352 & 0.218 & 0.193 & 0.440 & 0.286 \\
\hline SE & 0.344 & 0.559 & 0.370 & 0.417 & 0.563 & 0.513 \\
\hline $\mathrm{HA}$ & 0.294 & 0.530 & 0.343 & 0.400 & 0.537 & 0.477 \\
\hline LSD 5\% & \multicolumn{2}{|l|}{ A 0.022} & B 0.010 & \multicolumn{2}{|c|}{ C 0.012} & ABC NS \\
\hline \multicolumn{7}{|c|}{ Chlorophyll A/ Chlorophyll B } \\
\hline Water & 5.644 & 3.579 & 5.151 & 5.819 & 2.575 & 3.756 \\
\hline SE & 2.787 & 2.869 & 2.886 & 2.571 & 2.267 & 2.910 \\
\hline $\mathrm{HA}$ & 4.914 & 2.122 & 4.333 & 2.188 & 2.834 & 2.284 \\
\hline LSD 5\% & A NS & \multicolumn{2}{|c|}{ B 0.176} & C 0.24 & \multicolumn{2}{|c|}{ ABC NS } \\
\hline
\end{tabular}

(K20, 20 kg K2O/ fad; K40, 40 kg K2O/ fad; K80, 80 kg K2O/ fad; SE, seaweed extract; HA, humic acid)

The obtained results indicated that application of SE increased total chlorophyll and carotenoids contents of potato leaves. Our findings coincide with some earlier finding on Vigna sinensis (Sivasankari et al., 2006), Cyamopsis tetragonoloba (L.) Taub and Abelmoschus esculentus (L,) Moench (Thirumaran et al. 2009) and tomato (Zodape et al., 2011). Earlier studies by Whapham et al. (1993) had shown that the betaines present in extracts of $A$. nodosum, when used in the cucumber cotyledon bioassay 
devised for cytokinins (Fletcher, 1982), resulted in enhanced chlorophyll levels in comparison to the controls. These data strongly indicated that the effects on leaf chlorophyll contents produced by the use of seaweed extracts are due to the betaines contained in them.

It is well noted from the present results that EM had a simulative effect on all photosynthetic pigments fraction concentrations during the two growing seasons. The enhancing effects of bio fertilizers on chlorophylls concentration and their content may be attributed to their effects on increasing not only mineral uptake (Hauka, 2000) but also the production of growth substances especially cytokinins (Omay et al., 1993). Cytokinins are known to stimulate chlorophyll synthesis and delay chlorophyll destruction and senescence (Daiziel and Lawrence, 1984). Subba Rao, (1993) added that, the beneficial effects of bacterization on chlorophylls may be attributed to $\mathrm{N}_{2}$-fixation process, and/or to the production of growth promoting substances like gibberellins and other compounds of auxin type which gave a positive effect of plant growth, chlorophyll content nutrient uptake (Bashan and Holguim, 1997). Moreover, the increase of chlorophylls and carotenoides due to EM treatment may be attributed to the effects of phosphate-dissolving bacteria on decreasing soil $\mathrm{pH}$, increasing the availability of some nutrients such as $\mathrm{Fe}$, $\mathrm{Zn}, \mathrm{Mn}$ and $\mathrm{Cu}$ to plant uptake, potassium content (El-Shahawy, 2003), stimulating and surviving nitrogen fixing bacteria such as Azospirillum (Algawady and Gaur, 1988).

\section{Stem anatomy :}

The data presented in table (7) and illustrated in figures $(6,7,8)$ showed, in most cases, that addition of potassium fertilizer rates from 20 (control) to $80 \mathrm{Kg} \mathrm{K} 2 \mathrm{O} /$ fed increased stem and pith diameter, collenchyma thickness, chlorenchymatous layer thickness, length and width of vascular bundle, as well as the thickness of phloem and xylem. The results also indicated that the best treatment for increasing the thickness of either stem or collenchyma as well as the width of vascular bundle was addition of $40 \mathrm{Kg}$ $\mathrm{K}_{2} \mathrm{O} / \mathrm{fed}$. On the other hand, an addition of $80 \mathrm{~kg} \mathrm{~K} \mathrm{~K}_{2} \mathrm{O} / \mathrm{fed}$ gave the highest values of thickness of chlorenchymatous tissue, length of vascular bundle, thickness of internal and external phloem as well as thickness of xylem.

As regard to the effect of effective microorganisms, the data in the same table and figures clearly showed that inoculation of potato plants with EM increased the diameter of stem, number of parenchymatous layer, length and width of vascular bundle, and the thickness of external phloem and xylem, meanwhile decreased the diameter of pith, and the thickness of epidermis, collenchyma layers, and, internal phloem tissue. Foliar application of both biostimulants, in particular, seaweed extract increased, in most cases, all studied anatomical characteristics of potato stem, where its application increased the diameter of stem, pith and thickness of collenchyma layers, and xylem tissue as well as the length and width of large vascular bundle beside the thickness of external phloem. On the other hand, the thickness of internal phloem tissue was decreased. The same Table and figures indicated that, in most cases, all interactions increased all anatomical characteristics of potato stem. 
Arafa, A.A. et al. 
The highest values for thickness of epidermis, collenchyma and external phloem as well as stem diameter were obtained due to inoculated potato plants with effective microorganisma and foliar spraying with seaweed extract under moderate potassium fertilizer rate $\left(40 \mathrm{~kg} \mathrm{~K} \mathrm{~K}_{2} \mathrm{O} / \mathrm{fed}\right)$. Meanwhile, foliar spraying with seaweed extract without effective microorganisms inoculation under $40 \mathrm{~kg} \mathrm{~K} \mathrm{~K}_{2} \mathrm{O} / \mathrm{fed}$ showed the highest diameter of pith. The data also indicated that the highest values of large vascular bundle width and thickness of xylem tissue were obtained due to foliar application of humic acid in the absence of effective microorganisms inoculation under $80 \mathrm{~kg} \mathrm{~K} \mathrm{~K}_{2} \mathrm{O} / \mathrm{fed}$. On the other hand, foliar application of either humic acid or seaweed extract under $40 \mathrm{~kg} \mathrm{~K} \mathrm{~K}_{2} \mathrm{O} / \mathrm{fed}$ without inoculation with effective microorganisms gave the highest values of length of large vascular bundle and thickness of internal phloem tissue. Regarding the thickness of parenchyma tissue, the data in the same table and figure proved that the highest thickness of chlorenchymatous tissue could be attained after foliar application of humic acid under $40 \mathrm{~kg}$ $\mathrm{K}_{2} \mathrm{O} / \mathrm{fed}$ with effective microorganisms inoculation.

The increase in stem diameter under experimental factors may be attributed to its effects on enhancing nitrogen uptake and content in plant tissues (unpublished data). These nutrients induced meristimatic activity as well as cell division and its elongation through auxin production (Salem 2000). El-Rewainy, Hamdia and Galal, Anaam (2004) who reported that, nitrogen not only increased the growth substances but also increase their translocation in the plant. In addition, phosphorus is a component of RNA and DNA (Marschner 1995), therefore it play an important role for cell division activity. Moreover, the increase in stem diameter due to the inoculation with mixed three strains of used bacteria may be attributed to their ability to release plant growth substances, mainly IAA, GA3 and cytokinines (Omay et al. 1993). Auxins and cytokinins increased cell division and cell enlargement (Arteca 1996). He added that the exogenous application of cytokinins promote cell enlargement caused by an increase of water uptake as a result of an increase in the osmotic potential of the cells. Moreover, the increase in vascular bundle dimensions may be due to stimulation in cell division in the procambium and extension growth.

It could be concluded that application of $40 \mathrm{~kg} \mathrm{~K} \mathrm{~K}_{2} \mathrm{O} / \mathrm{fed}$ with addition of effective microorganisms and spraying plants with $500 \mathrm{mg} / \mathrm{l}$ seaweed extract proved to be more effective in improving plant growth, photosynthetic pigments as well as stem anatomy as compared with control plant. 
Arafa, A.A. et al.
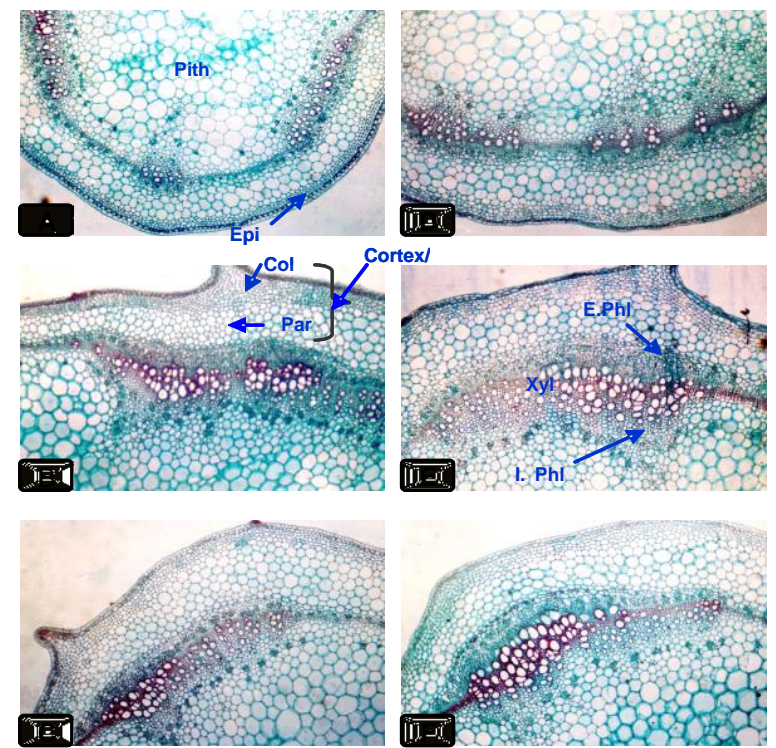

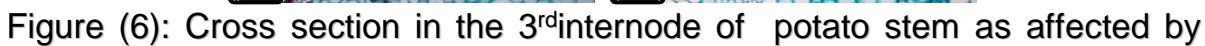
effective microorganisms, biostimulants under $20 \mathrm{Kg} \mathrm{K} 2 \mathrm{O} / \mathrm{fed}$ at 90 days from planting in the second season (E.Phl, External phloem; I. Phl, Internal phloem; Epi, Epidermis; Col, Collenchyma; Par, Parenchyma;Xyl, Xylem; A,1; B, 2; C,3; D,4; E, $5 ; F, 6)(40 x)$
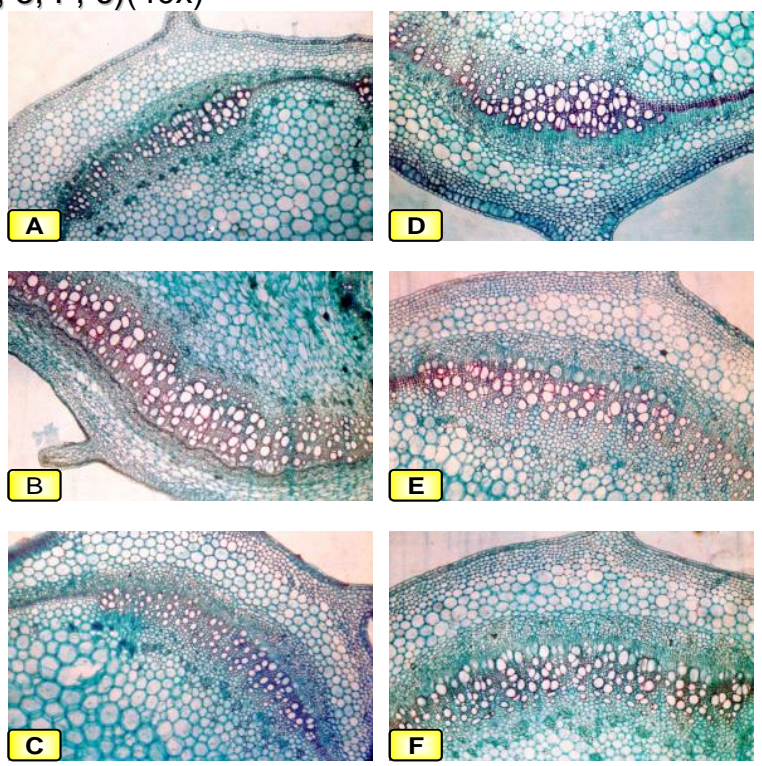

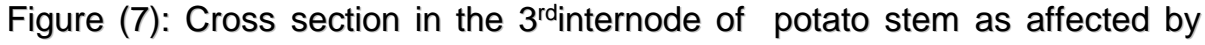
effective microorganisms, biostimulants under $40 \mathrm{Kg} \mathrm{K} 2 \mathrm{O} / \mathrm{fed}$ at 90 days from planting in the second season $(A, 7 ; B, 8 ; C, 9 ; D, 10 ; E$, $11 ; F, 12)(40 x)$ 

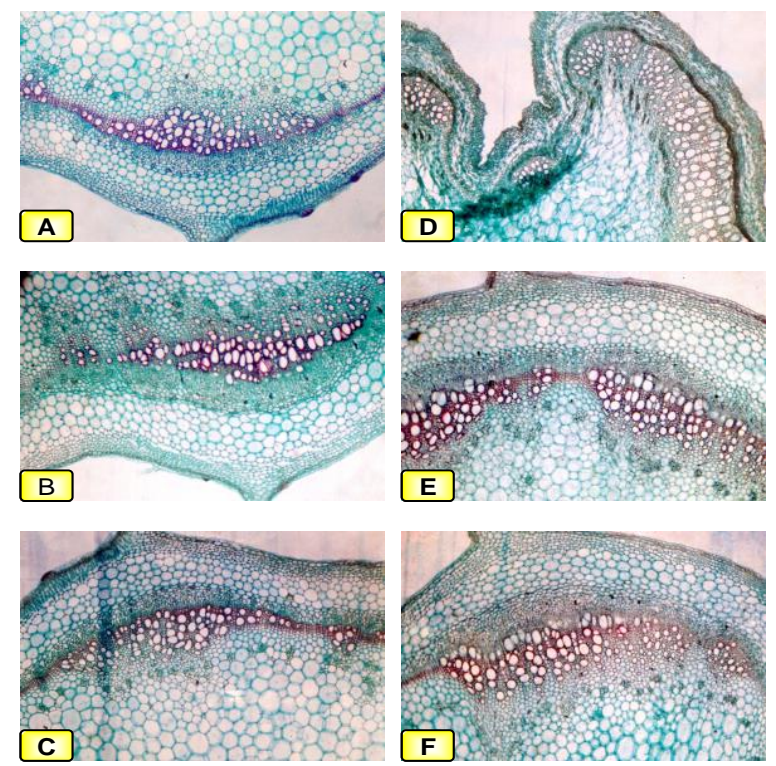

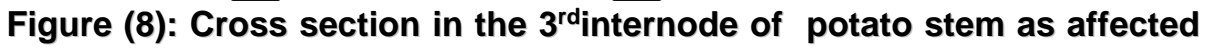
by effective microorganisms, biostimulants under $80 \mathrm{Kg}$ $\mathrm{K}_{2} \mathrm{O} /$ fedat 90 days from planting in the second season $(A, 13$; $B, 14 ; C, 15 ; D, 16 ; E, 17 ; F, 18)(40 x)$

\section{REFERENCES}

Abd El-Hadi A.H., M.S. Khadr and M.H. Taha (1997). Cotton fertilization under the intensive cropping system in Egyptian agriculture. Proceedings IRCRN Joint Meeting of the Working Groups on cotton. Cairo, Egypt. 147-154.

Abou-Bakr M.H.A., H.R. Hassan and M.A. Nassar Dalia, (2005). Effect of soil treatment with effective microorganisms as bio-ertilizer on morphological characters, yield and anatomical structure of potato plant (Solanum tuberosum L). J. Agric. Sci., Mansoura Univ., 30(11): 6701-6721.

Ahmed A. A., M.M.H.A. El-Baky, F.S.A. El-Aal and M.F. Zaki (2009). Comparative studies of application both mineral and bio-potassium fertilizers on the growth, yield and quality of potato plant. Research Journal of Agriculture and Biological Sciences. 5 (6):1061-1069.

Algawady R.A. and A.C. Gaur (1988). Interaction between Azospirillum brasilense and phosphate solubilizing bacteria and their influence on yield and nutrition uptake of sorghum. Ger. Zentrabaibl. Microbiol., 143: 637643.

Apte R. and S.T. Shende (1981). Studies on Azotobacter chroococum and their effect on crop yield. Zbl. Bakt. 136:637-640. 
Arafa, A.A. et al.

Arteca R.N. (1996). Plant growth substances principles and application. Chapman and Hall Press, New York. pp 613-616.

Bashan Y. and G. Holguim (1997). Azospirillum-plant relationship: Environmental and physiological advances (1990-1996). Can. J. Micrbiol., 43:103-121.

Bhattacharyya Ajit, Debasish Borah and M. Saikia (2009). Effect of potassium on growth, total tuber yield and residual status of nutrients on true potato seed transplants. Crop Research (Hisar). 38(1/3): 88-91.

Cakmak I., C. Hengeler and H. Marschner (1994). Partitioning of shoot and root dry matter and carbohydrates in bean plants suffering from phosphorus, potassium and magnesium deficiency. J. Exp. Bot. 45:1245-1250.

Crouch I.J. and J. Van Staden. (1993). Evidence for the presence of plant growth regulators in commercial seaweed products. Plant Growth Regulation. 13(1): 21-29.

Daiziel J. and D.K.Lawrence (1984). Biochemical and biological effects of Kaureneoxidase inhibitors, such as paclobutrazol. In R. Menhenett, D.K.Lawerence, eds. Biochemical aspects of synthetic and naturally occurring . Plant Growth Regulators. Monograph.

El-Ghamry A.M., K.M. Abd El-Hai and K.M. Ghoneem (2009). Amino and Humic Acids Promote Growth, Yield and Disease Resistance of Faba Bean Cultivated in Clayey Soil. Australian Journal of Basic and Applied Sciences, 3(2): 731-739.

El-Rewainy, Hamdia M. and Anaam H. Galal (2004). Effect of inoculation with Azospirillum brasilense or Bacillus megatherium on maize yield and its attributes under nitrogen or phosphorus fertilization levels. Assiut J. Agric. Sci., 35(1):145-163.

El-Sawy M.B.I. (2011). Effect of soil fertilization and foliar spray of potassium on vegetative growth and yield and its component of sweet poato. J. Plant Production, Mansoura University 2(3):437-452.

El-Shahawy, A.M.B. (2003.) Effect of phosphate dissolving bacteria on yield and nutrient uptake of faba bean and wheat plants. Ph. D. Thesis, Fac. of Agric., Mansoura Univ., Egypt.

Ezzat A.S., H. EL-S Asfour and M.H. Tolba (2011). Improving yield and quality of some new potato varities in winter plantation using organic stimulators. J. Plant Production, Mansoura Univ., 2(5):653-671.

Fabeiro C., F. Martı'n de Santa Olalla and J.A. de Juan (2001). Yield and size of deficit irrigation potatoes. Agric. Water Manage. 48:255-266.

Fike J.H.,V.G. Allen, R.E. Schmidt, X. Zhang, J.P. Fontenot, C.P. Bagley, R.L. Ivy, R.R. Evans, R.W. Coelho and D.B. Wester (2001). Tasco-Forage: I. Influence of a seaweed extract on antioxidant activity in tall fescue and in ruminants. J Anim Sci 2001. 79:1011-1021.

Fletcher R.A. (1982) An improved bioassay for cytokinins using cucumber cotyledons. Plant Physiol. 69: 675-677.

Hauka F.I.A. (2000). Effect of using single and composite inoculation with Azospirillum brasilense, Bacillus megaterium var. phosphaticum and Glomus macocarpus for improving growth of Zea mays. Egypt J. Agric. Sci., Mansoura Univ., 25(4):2327-2338. 
Higa T. (1995). Effective microorganisms: Their role in Kyusei Nature Farming and sustainable agriculture. In J.F. Parr, S.B. Hornick, and M.E. Simpson (ed.) Proceedings of the Third International Conference on Kyusei Nature Farming. U.S. Department of Agriculture, Washington, D.C., USA. (In Press).

Lichtenthaler, H.K. and A.R. Wellbun (1985). Determination of total carotenoids and chlorophylls A and B of leaf in Different Solvents. Biol. Soc. Trans 11: 591-592.

Marschner H. (1995): Mineral Nutrition of higher plants. $2^{\text {nd }}$ Ed .Academic press. London.

Mengel K. and W.W. Arneke (1982). Effect of potassium on the water potential, the pressure potential, the osmotic potential and cell elongation in the leaves of Phaseolus vulgaris. Physiol. Plant, 54: 402-408.

Moinuddin, Komal Singh and S.K. Bansal (2005). Growth, yield, and economics of potato in relation to progressive application of potassium fertilizer. Journal of Plant Nutrition. 28(1):183-200.

Muscolo A., F. Bavolo, F. Gionfriddo and S. Nardi (1999). Earthworm humic matter produced auxin-like effects on Daucus carota cell growth and nitrate metabolism. Soil Biol. Biochem. 31:1303-1311.

Nardi S., G. Concheri and Dell Angola (1996). Biotical activity of hamic substances . In: piccolo A., (Ed.) Hamic substances in Terrestrial Ecosystems, Elsevier. Amsterdam, PP.361-406.

Nijjar G.S. (1985). Nutrition of fruit trees. Usha Raji Kumar, Kalyani, New Delhi, India, pp 10-20

Omay S.H.,W.A. Schmidt and P. Martin (1993). Indole acetic acid productivity by rhyzosphere bacterium Azospirillum brasilense C.D. under in vitro condition. Can. J. Microbiol., 39:187-192.

Pascual J.A., C. Garcia and T. Hernandez (1999). Comparison of fresh and composted organic waste in their efficacy for the improvement of arid soil quality. Bioresources Technol., 68: 255-64.

Perrenoud S. (1993). Fertilizing for high yield potato. IPI Bulletin 8. $2^{\text {nd }}$ Edition, International Potash Institute, Basel, Switzerland.

Piccolo A., G. Pietramellara and J.S.C. Mbagwu (1997) Reduction in soil loss from erosion-susceptible soils amended with humic substances from oxidized coal. Soil Technol., 10: 235-245.

Piccolo A., S. Nardi and G. Concheri (1992). Structural characteristics of humic substances as regulated to nitrate uptake and growth regulation in plant systems. Soil Biochem., 24:373-380.

Pondey S.N. and A. Chadha (1996). Economic Botany, New Dalhi, press p. 5758.

Rai G.K., M.M. Verma and Jagdish Singh (2004). Effect of potassium and nitrogen on yield and quality of potato (Solanum tuberosum L.) tubers. Indian Journal of Agricultural Biochemistry.17 (1):45-46.

Sahai V.N. (2004). Mineral Nutrients. In Fundamentals of Soil. $3^{\text {rd }}$ Edition. Kalyani Publishers, New Dehli, India. pp:151-155. 
Arafa, A.A. et al.

Saif El-Deen U.M., A.S. Ezzat and A.H.A. EL-Morsy (2011). Effect of phosphorous fertilizer rates and application methods of humic acid on productivity and quality of sweet potato. J. Plant Production, Mansoura Univ., 2(1):53-66.

Salem M.A.(2000).Response of maize (Zea mays L) growth and yield to chemical and bio-fertilization. Zgazig J.Agric.Res., 27(4): 845-858.

Salisbury F.B. (1994). The role of plant hormones. In Plant- Environment Interactions. Ed. R E Wilkinson. pp. 39-81. Marcel Dekker, New York, USA.

Sanderson K.J., P.E. Jameson and J.A. Zabkiewicz (1987). Auxin in a seaweed extract: Identification and quantitation of indole- 3-acetic acid by gas chromatography-mass spectometry. J. Plant Physiol. 129:363-367.

Sangakkara U.R., M. Frehner and J. Nosberger (2000). Effect of soil moisture and potassium fertilizer on shoot water potential, photosynthesis and partitioning of carbon in mungbean and cowpea. J. Agron. Crop Sci. 185: 201-207.

Sarig S., Y. Kapulnik and Y. Okon (1984). Response of non-irrigated Sorghum bicolor to Azospirillum inoculation. Exp.Agric. 20:59-66.

Schank S.C., K.L. Weier and I.C. Macrae (1981). Plant yield and nitrogen content of a digitgrass in response to Azospirillum inoculation. Appl. Environ. Microbiol. 41:342-345.

Seadh S.E, M.I. EL-Abady, S. Farouk and Amal E.A. EL-Saidy (2008). Effect of foliar nutrition with humic and amino acids under $\mathrm{N}$-levels on wheat productivity and quality of grains and seeds. Egyptian Journal of Applied Sciences 23 (12B): 543-558.

Shehata S.A and F.A. Abo-sedera (1994). Effect of irrigation frequency and N.K. level on growth, yield, chemical composition and storage-ability of potato. Zagazig J. Agric . Res . 12(1):129-143.

Sivasankari S., M. Chandrasekaran, K. Kannathasan and V. Venkatesalu (2006). Studies on the biochemical constituents of Vigan radiate Linn. treated with seaweed liquid fertilizer, Seaweed Res.Utiln.28(1):51-158.

Sridhar S. and R. Rengasamy (2002). Effect of seaweed liquid fertilizer obtained from Ulva lactuca on the biomass, pigments and protein content of Spirulina platensis. Seaweed Res. Utiln., 24:145-149.

Subba Rao N.S. (1993). Bio-fertilizers in agricultures and foresty. $3^{\text {rd }}$ Ed. Oxford and IBH Publishing Co. Pvt. Ltd., New Delhi, Bomba, Calcutta, 219 pp.

Sundaravelu S. and T. Muthukrishinan (1993). Effect of seed treatment with Azospirillium and gibberellic acid on the growth and yield of radish. South India Hort. 41(4):212-213.

Thirumaran G., M. Arumugam, R. Arumugam and P. Anantharaman (2009). Effect of Seaweed Liquid Fertilizer on Growth and Pigment Concentration of Cyamopsis tetrogonolaba (L) Taub. American-Eurasian Journal of Agronomy 2 (2): 50-56

Valdrighi M.M., A. Pear, M. Agnolucci, S. Frassinetti, D. Lunardi and G. Vallini (1996). Effects of compost-derived humic acids on vegetable biomass production and microbial growth within a plant (Cichorium intybus) soil system: a comparative study. Agric. Ecosyst. Environ. 58:133-144. 
Verlinden G., B. Pycke, J. Mertens, F. Debersaques, K. Verheyen, G. Baert, J. Bries and G. Haesaert (2009). Application of humic substances results in consistent increases in crop yield and nutrient uptake. Journal of Plant Nutrition 32 (9):1407-1426.

Whapham C.A., G. Blunden, T. Jenkins and S.D. Hankins (1993). Significance of betaines in the increased chlorophyll content of plants treated with seaweed extract. J. Appl. Phycol. 5: 231-234.

Zhang X., E.H. Ervin and R.E. Schmidt. 2003. Plant growth regulators can enhance the recovery of Kentucky bluegrass sod from heat injury. Crop Sci. 43:952-956.

Zodape S.T., Abha Gupta, S.C. Bhandari, U.S. Rawat, D.R. Chaudhary, K. Eswaran and A. Chikara (2011). Foliar application of seaweed sap as biostimulant for enhancement of yield and quality of tomato (Lycopersicon esculentum Mill.). J. of Scientific and Industrial Research, 70: 215-219.

Zodape S.T., V.J. Kawarkhe, J.S. Patolia and A.D. Warade (2008). Effect of liquid seaweed fertilizer on yield and quality of okra (Abelmoschus esculentus L.). J. of Scientific and Industrial Research, 67:1115-1117

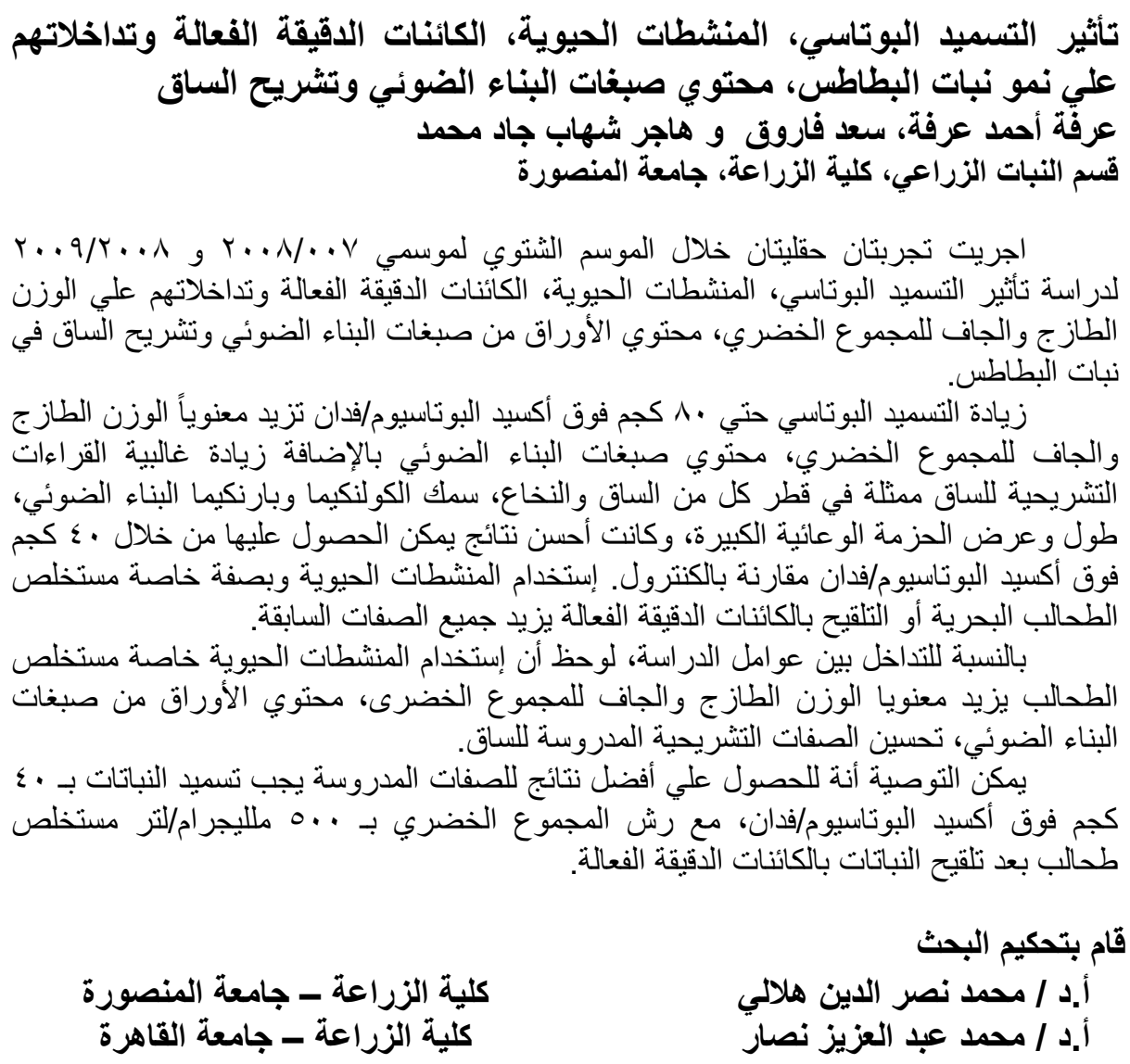


Table (7): Anatomical characteristics of potato stem as affected by potassium fertilizer rate, effective microorganism and biostimulants as well as their interactions at $\mathbf{9 0}$ days from planting during the second growing season

\begin{tabular}{|c|c|c|c|c|c|c|c|c|c|c|c|c|c|c|}
\hline & \multirow{3}{*}{\multicolumn{2}{|c|}{ Treatment }} & \multirow{3}{*}{ 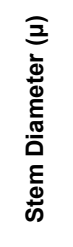 } & \multirow{3}{*}{ 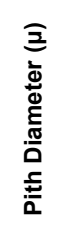 } & \multirow{3}{*}{ 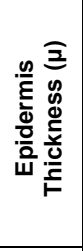 } & \multirow{2}{*}{\multicolumn{4}{|c|}{ Cortex thickness $(\mu)$}} & \multirow{2}{*}{\multicolumn{2}{|c|}{ 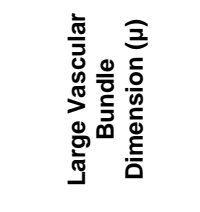 }} & \multirow{3}{*}{ 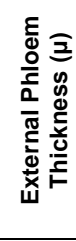 } & \multirow{3}{*}{ 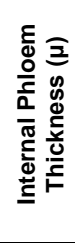 } & \multirow{3}{*}{ 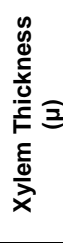 } \\
\hline & & & & & & & & & & & & & & \\
\hline & & & & & & Number & Thickness & Number & Thickness & Length & Width & & & \\
\hline \multirow{6}{*}{ K20 } & \multirow{3}{*}{$-E M$} & W (1) & 1850 & 838 & 12 & 6 & 110 & 4 & 220 & 164 & 168 & 42 & 50 & 72 \\
\hline & & SE (2) & 2530 & 1142 & 12 & 6 & 150 & 4 & 200 & 332 & 368 & 50 & 78 & 204 \\
\hline & & $\mathrm{HA}(3)$ & 2320 & 1288 & 8 & 5 & 120 & 5 & 230 & 158 & 324 & 44 & 46 & 68 \\
\hline & \multirow{3}{*}{$+\mathrm{EM}$} & W (4) & 2100 & 1104 & 8 & 5 & 90 & 5 & 180 & 220 & 320 & 30 & 26 & 156 \\
\hline & & SE (5) & 2650 & 1026 & 12 & 5 & 160 & 5 & 300 & 340 & 348 & 90 & 78 & 172 \\
\hline & & $\mathrm{HA}(6)$ & 2650 & 1462 & 4 & 6 & 120 & 3 & 250 & 220 & 328 & 50 & 58 & 112 \\
\hline \multirow{6}{*}{ K40 } & \multirow{3}{*}{$-E M$} & W (7) & 2450 & 1200 & 8 & 5 & 130 & 4 & 250 & 252 & 260 & 66 & 62 & 124 \\
\hline & & SE (8) & 3400 & 1568 & 8 & 5 & 160 & 7 & 380 & 368 & 320 & 114 & 94 & 160 \\
\hline & & $\mathrm{HA}(9)$ & 3250 & 1558 & 8 & 5 & 150 & 5 & 260 & 368 & 252 & 98 & 114 & 156 \\
\hline & \multirow{3}{*}{$+\mathrm{EM}$} & W (10) & 2820 & 1408 & 12 & 7 & 130 & 4 & 300 & 264 & 248 & 70 & 62 & 132 \\
\hline & & SE (11) & 3370 & 1538 & 16 & 6 & 160 & 5 & 420 & 320 & 292 & 100 & 64 & 156 \\
\hline & & HA (12) & 3250 & 1498 & 12 & 4 & 150 & 5 & 430 & 284 & 260 & 60 & 50 & 174 \\
\hline \multirow{6}{*}{$\mathrm{K} 80$} & \multirow{3}{*}{$-E M$} & W (13) & 2160 & 676 & 12 & 6 & 120 & 5 & 310 & 300 & 208 & 74 & 70 & 156 \\
\hline & & SE (14) & 2560 & 1204 & 8 & 4 & 100 & 5 & 310 & 260 & 340 & 78 & 50 & 132 \\
\hline & & HA (15) & 2400 & 1092 & 4 & 5 & 100 & 8 & 250 & 300 & 380 & 48 & 52 & 200 \\
\hline & \multirow{3}{*}{$+\mathrm{EM}$} & W (16) & 2250 & 978 & 8 & 9 & 150 & 4 & 250 & 228 & 260 & 50 & 66 & 112 \\
\hline & & SE (17) & 3200 & 1532 & 12 & 5 & 90 & 8 & 400 & 332 & 360 & 88 & 90 & 154 \\
\hline & & HA (18) & 2950 & 1438 & 8 & 5 & 120 & 5 & 300 & 328 & 288 & 78 & 110 & 140 \\
\hline
\end{tabular}

$\left(\mathrm{K}_{\mathbf{2 0}}, \mathbf{2 0} \mathbf{~ k g ~ K} \mathrm{K}_{\mathbf{2}} \mathrm{O}\right.$ / fed; $\mathrm{K}_{\mathbf{4 0}}, \mathbf{4 0} \mathbf{~ k g ~ K} \mathbf{~}_{\mathbf{2}} \mathrm{O}$ / fed; $\mathrm{K}_{\mathbf{8 0}}, \mathbf{8 0} \mathbf{~ k g ~ K} \mathrm{K}_{\mathbf{2}} \mathrm{O} /$ fed; SE, seaweed extract; HA, humic acid; EM, Effective microorganisms) 